\title{
Philosophiques
}

\section{Résumés des articles - Abstracts of Articles}

Volume 1, numéro 2, octobre 1974

URI : https://id.erudit.org/iderudit/203014ar

DOI : https://doi.org/10.7202/203014ar

Aller au sommaire du numéro

Éditeur(s)

Société de philosophie du Québec

ISSN

0316-2923 (imprimé)

1492-1391 (numérique)

Découvrir la revue

Citer ce document

(1974). Résumés des articles - Abstracts of Articles. Philosophiques, 1(2), 79-82. https://doi.org/10.7202/203014ar d'utilisation que vous pouvez consulter en ligne.

https://apropos.erudit.org/fr/usagers/politique-dutilisation/ 


\section{RÉSUMÉ DES ARTICLES ABSTRACTS OF ARTICLES}

\section{LOUIS VALCKE}

\section{Le Monisme épistémologique de la Science contemporaine}

L'auteur part du postulat d'objectivité de la méthode scientifique dans son affirmation d'une distinction radicale entre le sujet qui observe et l'objet observé. Il montre en quoi ce dualisme du sujet et de l'objet a été remis en question dans la physique quantique de Heisenberg et dans la psychologie behavioriste de Watson. Cependant, l'auteur soutient que le dépassement de ce dualisme cartésien par le monisme objectiviste (Monod) ou par le monisme subjectiviste (Eddington) est impossible pour la raison très simple que le monisme est impensable. De fait, le monisme a été pensé, mais dans un langage dualiste.

The author begins with the postulate of the objectivity of the scientific method in its affirmation of a radical distinction between the subject who observes and the object which is observed. It is shown how this dualism of subject and object was put into question in Heisenberg's quantum physics and in Watson's behaviorist psychology. Nevertheless, the author holds that the overcoming of cartesian dualism by objectivist monism (Monod) or by subjectivist monism (Eddington) is impossible. The very simple reason for this claim is that monism is unthinkable. Actually, monism has been thought, but it has been thought in a dualist language. 


\section{PETER MCCORMICK}

\section{Heidegger sur le chemin du langage}

La méditation la plus importante d'Heidegger sur le langage s'intitule «Le chemin vers le langage »; c'est le dernier chapitre d'Unterwegs zur Spracbe. Si nous considérons la possibilité que le dernier Heidegger a quelque chose à apporter aux problèmes philosophiques du langage, nous devons déterminer exactement ce que Heidegger pense dans cette méditation. C'est pourquoi ma communication se bornera à une lecture détaillée et très restreinte de ce texte. La tâche plus intéressante mais, compte tenu de l'état des études sur Heidegger, moins prioritaire, c'est-à-dire l'évaluation des propos heideggeriens, et leur incorporation dans une optique plus large sur la philosophie du langage, m'occupera à une autre occasion. Je prendrai comme points d'appui l'introduction prolongée de la méditation heideggerienne et sa conclusion. Dans un troisième et plus court moment, je mettrai ensemble les résultats de ces deux premières analyses pour faire le point sur les éléments de base du dernier Heidegger sur le langage. Partout, mon intention serait d'ouvrir la possibilité d'une discussion dont les éléments essentieis seraient en fin délimités.

Heidegger's most important meditation on language is «The Way to Language, » the final chapter of Unterwegs zur Sprache. If we are to decide whether Heidegger has anything of substance to contribute to present concerns with philosophical problems of language, we need to determine what he is saying. This paper is concerned with the latter point. My central concern here will be to formulate as carefully as I can just what Heidegger seems to be saying about language. The more interesting task of evaluating claims, and this icorporation into a larger view of the philosophy of language, will concern me on another occasion. Althought Heidegger's meditation falls into three sections, I shall confine my analysis to his extended introduction and conclusion. For the priority here is clearly on the side of understanding Heidegger's starting point, aims, and procedures. After examining closely then Heidegger's programatic statements in his introduction and conclusion I shall combine the first with the second to formulate both Heidegger's central claims in this essay and their assumptions. 


\section{CLAUDE PANACCIO}

Langage ordinaire et langage abstrait chez Guillaume d'Occam

Utilisant surtout le traité De Sacramento Altaris, l'auteur essaie de montrer que, bien que l'opposition langage ordinaire/ langage philosophique soit effectivement présente chez Guillaume d'Occam, sa critique logique du discours abstrait n'a cependant rien à voir, quoi qu'en pensent certains commentateurs, avec la philosophie contemporaine du langage ordinaire, puisqu'elle trouve son critère et sa norme dans un discours mental, naturel, universel et prélinguistique. De façon plus générale, l'article vise à mettre au jour certains présupposés épistémologiques qui doivent être dépassés pour qu'une «philosophie du langage ordinaire » devienne historiquement possible.

This paper, mostly based upon the tract De Sacramento Altaris, tries to show that, although the contrast between ordinary language and philosophical language can be found in Ockham's writings, his logical criticism of abstract discourse has nothing to do with contemporary philosophy of ordinary language and that it has been misinterpretated by some commentators. On the contrary, the criteria of Ockham's criticism lies in a natural, universal, and prelinguistic mental discourse. In a more general way, the author holds that some epistemological postulates which underlie all of medieval philosophy (at least up to and including William of Ockham) had to be abandoned, so that ordinary language philosophy could become historically possible.

\section{GUY H. ALLARD}

\section{L'Enigme et la Culture littéraire d'Augustin}

Après avoir montré brièvement la place et le rôle de l'énigme en culture littéraire, cet article s'attache à montrer les procédés littéraires à l'oeuvre dans l'analyse augustinienne de deux grandes énigmes : l'homme-individu, l'homme-société. L'énigme qu'Augustin trouve au fond de l'homme, c'est d'abord une controversia (terme rhétorique par excellence), conflit qui le conduit à postuler la présence de ce qu'on appelle aujourd'hui l'inconscient; mais ici l'herméneutique est menée avec des concepts littéraires 
et non médico-biologiques. D'autre part, les rapports sociaux de l'homme ne sont pas analysés en termes de production, ni de pouvoir politique, mais plutôt en référence aux mythologies reilgieuses, c'est-à-dire en fonction de l'interprétation du Livre. Loin d'être économico-politique, le déchiffrage repose sur la manière dont Romains, Juifs, chrétiens, manichéens, donatistes lisent les signes de l'Ecriture. L'article s'achève enfin sur une brève description de l'épistémologie qui organise les lignes de force de cette herméneutique.

After briefly showing the place and the role of the enigm in literary culture, this article goes on to show the literary procedures at work in the Augustinian analysis of two great enigmas: man-individual, man-society. The enigma which Augustin finds at the basis of man is first of all a controversia (a thetorical term par excellence), a conflict which leads him to postulate the presence of what today is called the unconscious. But here hermeneutics is pursued with literary rather than with medico-biological concepts. Moreover, man's social relations are not analysed in terms of production, nor of political power, but with reference to religious mythologies, that is, as a function of the interpretation of the Book. Far from being an economic and political interpretation, the interpretation here is based on the way Romans, Jews, Christians, Manicheans, and Donatists read the signs of scripture. The article concludes with a short description of the epistemology which organizes the lines of force of this hermeneutic. 